University of Nebraska - Lincoln

DigitalCommons@University of Nebraska - Lincoln

Publications from USDA-ARS / UNL Faculty

U.S. Department of Agriculture: Agricultural

Research Service, Lincoln, Nebraska

2002

\title{
KURA CLOVER AND BIRDSFOOT TREFOIL RESPONSE TO SOIL pH
}

L. R. DeHaan

University of Minnesota

M. P. Russelle

University of Minnesota, russelle@soils.umn.edu

C. C. Sheaffer

University of Minnesota

N. J. Ehlke

University of Minnesota

Follow this and additional works at: https://digitalcommons.unl.edu/usdaarsfacpub

Part of the Agricultural Science Commons

DeHaan, L. R.; Russelle, M. P.; Sheaffer, C. C.; and Ehlke, N. J., "KURA CLOVER AND BIRDSFOOT TREFOIL RESPONSE TO SOIL pH" (2002). Publications from USDA-ARS / UNL Faculty. 586.

https://digitalcommons.unl.edu/usdaarsfacpub/586

This Article is brought to you for free and open access by the U.S. Department of Agriculture: Agricultural Research Service, Lincoln, Nebraska at DigitalCommons@University of Nebraska - Lincoln. It has been accepted for inclusion in Publications from USDA-ARS / UNL Faculty by an authorized administrator of DigitalCommons@University of Nebraska - Lincoln. 


\title{
KURA CLOVER AND BIRDSFOOT TREFOIL RESPONSE TO SOIL pH
}

\author{
L. R. DeHaan, ${ }^{1}$ M. P. Russelle, ${ }^{2, *}$ C. C. Sheaffer, ${ }^{1}$ and \\ N. J. Ehlke ${ }^{1}$ \\ ${ }^{1}$ Department of Agronomy and Plant Genetics, 411 Borlaug \\ Hall, and ${ }^{2}$ Department of Soil Water, and Climate, \\ USDA-ARS/U.S. Dairy Forage Research Center, \\ 439 Borlaug Hall, University of Minnesota, \\ 1991 Upper Buford Circle, St. Paul, MN 55108
}

\begin{abstract}
Use of the rhizomatous perennial forage legume kura clover (Trifolium ambiguum M. Bieb.) has been limited by slow establishment. Mature kura clover responds to liming on some acid soils, but the soil $\mathrm{pH}$ required for vigorous growth of young plants is unknown. A factorial greenhouse experiment was conducted with two kura clover cultivars (Rhizo and Endura) and one cultivar of birdsfoot trefoil (Lotus corniculatus L., Norcen) planted in three soil types (Sartell loamy fine sand, Hubbard loamy sand, and Sanborg clay loam) amended with $\mathrm{Ca}(\mathrm{OH})_{2}$ to obtain six soil $\mathrm{pH}$ levels. The experiment was performed twice, once using soil taken directly from the field and once using steamed soil. Response of kura clover and birdsfoot trefoil to soil $\mathrm{pH}$ differed. Maximum yield increases in kura clover obtained by adjusting soil $\mathrm{pH}$ from 4.9 to 6.5 were about $50 \%$ on nonsteamed
\end{abstract}

Joint contribution of the Minnesota Agricultural Experiment Station and USDA-ARS.

*Corresponding author. E-mail: russelle@ soils.umn.edu 
soil and more than $150 \%$ on steamed soil. Birdsfoot trefoil did not respond to liming on nonsteamed soil. On steamed soil birdsfoot trefoil response to liming was inconsistent. Optimal soil $\mathrm{pH}$ for growth of kura clover and birdsfoot trefoil was generally between $\mathrm{pH} 6$ and 7. Biomass yield was correlated with nodulation in both kura clover and birdsfoot trefoil, but nodulation was correlated with nitrogen uptake only in kura clover. Increased biomass yield of young kura clover plants in response to liming was best explained by alleviation of aluminum ( $\mathrm{Al})$, zinc ( $\mathrm{Zn})$, and manganese $(\mathrm{Mn})$ toxicities and increased availability of phosphorus (P) and molybdenum (Mo) at higher soil $\mathrm{pH}$ levels.

\section{INTRODUCTION}

Kura clover is a rhizomatous perennial forage legume with potential to be a major grazing crop due to its persistence under adverse environmental conditions (1). Major limitations to widespread adoption of kura clover have been low seedling vigor and slow establishment (2). Therefore, much research with the species has been conducted to determine the best management strategies for rapid establishment (3-5). However, the effect of soil $\mathrm{pH}$ on kura clover seedling growth has not been studied.

Liming of acid soils has been a traditional strategy to increase crop yields. Poor growth on acid soils is due largely the increased activity or solubility of Al and $\mathrm{Mn}$ at low $\mathrm{pH}$ levels (6). Both $\mathrm{Al}$ and $\mathrm{Mn}$ can be directly toxic to plants and decrease uptake of $\mathrm{Ca}$ and $\mathrm{Mg}$. Zinc can also reach toxic levels on acid soils (7). In contrast, $\mathrm{P}$ and Mo can become less available on acid soils due to their reaction with $\mathrm{Al}$ and iron (Fe) (6). Legumes can be especially sensitive to acid soils because the activity of some rhizobia species is reduced when soil $\mathrm{pH}$ is less than $6.0(8)$.

A pH greater than 7.0 can limit crop yields on some soils. As $\mathrm{pH}$ levels increase, the availability of all micronutrients except Mo is reduced (6). Highly weathered acid soils may be particularly susceptible to over-liming. Liming can cause deterioration in the structure of these soils and reduce the availability of some minerals (9).

Birdsfoot trefoil is regarded as one of the more acid tolerant forage legumes (10). The percent yield increase of established kura clover in response to liming was about equal to alfalfa (Medicago sativa L.), and 2.5 to 4 times greater than birdsfoot trefoil $(11,12)$. Liming increased forage yield of established "Rhizo" kura clover by $24 \%$ on a sandy soil in north central Minnesota (11).

Kura clover is persistent in harsh environments such as on acid soil, but it also responds to liming. A diploid line (CPI 2264) demonstrated persistence in an 
acid alpine environment and was superior to a tetraploid line (CPI 6884) (13). Both lines were more persistent than four hexaploid lines and Trifolium repens L., Trifolium hybridum L., and Trifolium fragiferum L. (13). The diploid cultivar Summit and the tetraploid cultivar Treeline persisted much better than T. repens on soil with low $\mathrm{pH}$ and extracted $\mathrm{P}$ and calcium $(\mathrm{Ca})$ more efficiently from acid soils (14).

Little is known about how kura clover will respond to liming on the variety of acid soils present in north central North America. On an acid, brown sandy clay loam Oxisol, low availability of copper $(\mathrm{Cu})$ and $\mathrm{Mo}$ limited growth of kura clover (12), but different soils may reveal additional possibilities for deficiencies or toxicities. The goals of this study were to compare kura clover and birdsfoot trefoil responses to soil $\mathrm{pH}$ during the establishment phase, and to determine the mineral toxicities and deficiencies that may limit growth of young kura clover plants on acid soils typical of the north central United States. Birdsfoot trefoil was included in the study because of its known tolerance to low $\mathrm{pH}$ soils.

\section{MATERIALS AND METHODS}

Two cultivars of kura clover, "Rhizo" and "Endura," and one cultivar of birdsfoot trefoil, "Norcen," were used. Rhizo was developed by selection for vigorous rhizomatous growth, persistence, and disease and insect resistance (15). Endura is a recently developed proprietary cultivar (Challenge Seeds, Ltd., New Zealand). Norcen is a nine-clone synthetic that is adapted to the mid-western United States (16).

Three soils were used: Sartell loamy fine sand (mixed, frigid Typic Udipsamment) was collected from a recently cleared forest in Saint Louis Co., MN; Sanborg clay loam (fine, mixed, active, frigid Oxyaquic Glossudalf) was collected from a cropped field in Ashland Co., WI; and Hubbard loamy sand (sandy, mixed, frigid Entic Hapludoll) was collected from a stand of red pines (Pinus resinosa Aiton) in Sherburne Co., MN. Soil was collected from the upper $25 \mathrm{~cm}$ of the profile at each location. All soils were tested for $\mathrm{pH}(1: 1 \mathrm{soil} /$ water, stirred), organic carbon (C), P (Bray 1), potassium (K), sulfur (S), Zn, Fe, magnesium $(\mathrm{Mg}), \mathrm{Cu}$, boron (B), $\mathrm{Ca}$, and $\mathrm{Mn}$ and fertilized according to the University of Minnesota soil test recommendation for legumes. The Sartell soil had a $\mathrm{pH}$ of 4.6, a SMP buffer index of 6.4 , contained $22 \mathrm{~g} \mathrm{~kg}^{-1} \mathrm{C}$, and was fertilized with $150 \mathrm{mg} \mathrm{kg}^{-1} \mathrm{~K}$. The Sanborg soil had a $\mathrm{pH}$ of 4.8 , a SMP buffer index of 6.1 , contained $13 \mathrm{~g} \mathrm{~kg}^{-1} \mathrm{C}$, and was fertilized with $10 \mathrm{mg} \mathrm{kg}^{-1} \mathrm{P}$, $113 \mathrm{mg} \mathrm{kg}^{-1} \mathrm{~K}$, and $11 \mathrm{mg} \mathrm{kg}^{-1} \mathrm{~S}$. The Hubbard soil had a $\mathrm{pH}$ of 5.0, a SMP buffer index of 6.8 , contained $5 \mathrm{~g} \mathrm{~kg}^{-1} \mathrm{C}$, and was fertilized with $8 \mathrm{mg} \mathrm{kg}^{-1} \mathrm{P}$, $77 \mathrm{mg} \mathrm{kg}^{-1} \mathrm{~K}, 9 \mathrm{mg} \mathrm{kg}^{-1} \mathrm{~S}, 0.8 \mathrm{mg} \mathrm{kg}^{-1} \mathrm{~B}$, and $29 \mathrm{mg} \mathrm{kg}^{-1} \mathrm{Mg}$. 
Ten 250-g samples were taken from each of the three soils and amended with a range of $\mathrm{Ca}(\mathrm{OH})_{2}$ concentrations. After allowing $14 \mathrm{~d}$ for partial equilibration, the $\mathrm{pH}$ of each sample was determined, and the results were used to construct a calibration curve for each soil. Using the curves, the levels of $\mathrm{Ca}(\mathrm{OH})_{2}$ required to obtain six roughly equally-spaced $\mathrm{pH}$ treatments from the starting $\mathrm{pH}$ to $\mathrm{pH} 7.5$ was determined. The Sartell soil was treated with $0,0.4,1.2$, 2.0, 2.8, and $4.4 \mathrm{~g} \mathrm{~kg}^{-1} \mathrm{Ca}(\mathrm{OH})_{2}$. The Sanborg soil was treated with 0, 0.4, 1.0, 1.6, 3.2, and $6.4 \mathrm{~g} \mathrm{~kg}^{-1} \mathrm{Ca}(\mathrm{OH})_{2}$. The Hubbard soil was treated with $0,0.2,0.4$, $0.6,1.0$, and $1.4 \mathrm{~g} \mathrm{~kg}^{-1} \mathrm{Ca}(\mathrm{OH})_{2}$. All of the soils were allowed to equilibrate for at least $21 \mathrm{~d}$. The soil $\mathrm{pH}$ of every pot was tested before planting and after harvesting, and the averages of the two tests were used in all calculations ( $\mathrm{pH}$ difference always $<1.0$ ).

Plastic pots $18 \mathrm{~cm}$ in diameter and $45 \mathrm{~cm}$ tall were filled with about $11 \mathrm{~kg}$ of soil, and about 45 seeds were planted in nine equally spaced locations. The kura clover was inoculated with a commercial mixture of Rhizobium leguminosarum biovar trifolii, and the birdsfoot trefoil was inoculated with a commercial mixture of Mesorhizobium loti. After $10 \mathrm{~d}$, the plants were thinned to nine plants per pot. Greenhouse temperature was maintained between 22 and $25^{\circ} \mathrm{C}$. Supplemental lighting (high pressure sodium vapor) was provided for $16 \mathrm{hd}^{-1}$ at about $90 \mu \mathrm{mol} \mathrm{s}{ }^{-1} \mathrm{~m}^{-2}$ photosynthetic photon flux. Plants were watered with deionized water to prevent plant water stress.

The experiment was conducted twice. The first trial was planted on 24 January 1997, and the second trial was planted on 20 September 1997. Before the second trial, the soil was steamed two times for $2 \mathrm{~h}$ with $5 \mathrm{~d}$ between steamings to reduce soil-borne pathogens. In both trials, three samples of each soil type having low, moderate, and high $\mathrm{pH}$ were taken immediately before planting and analyzed for several chemical constituents using standard extractants (University of Minnesota Soil Testing Laboratory), with the exception of Al, which was extracted with DTPA. Because the sampling was not replicated, statistical analysis of the data was not performed (Table 1).

Two harvests were performed when the birdsfoot trefoil was beginning to flower at 56 and $91 \mathrm{~d}$ after planting. The kura clover was vegetative at both harvests. At the first harvest, the plants were cut to a stubble height of $2.5 \mathrm{~cm}$. At the second harvest, the plants were dug, and the root portion was separated from the shoot at the crown. After harvesting, the plant material was washed with deionized water, dried at $60^{\circ} \mathrm{C}$ for $72 \mathrm{~h}$, and weighed.

Nodulation and leaf chlorosis were rated visually on a 1 to 5 scale. Chlorosis was rated before the second harvest on the percentage of leaf area that was chlorotic. Nodulation was rated only for kura grown on the Hubbard soil in the first trial, but all treatments were rated in the second trial. The nodulation rating was based on the number and size of nodules present after the roots had been washed. 


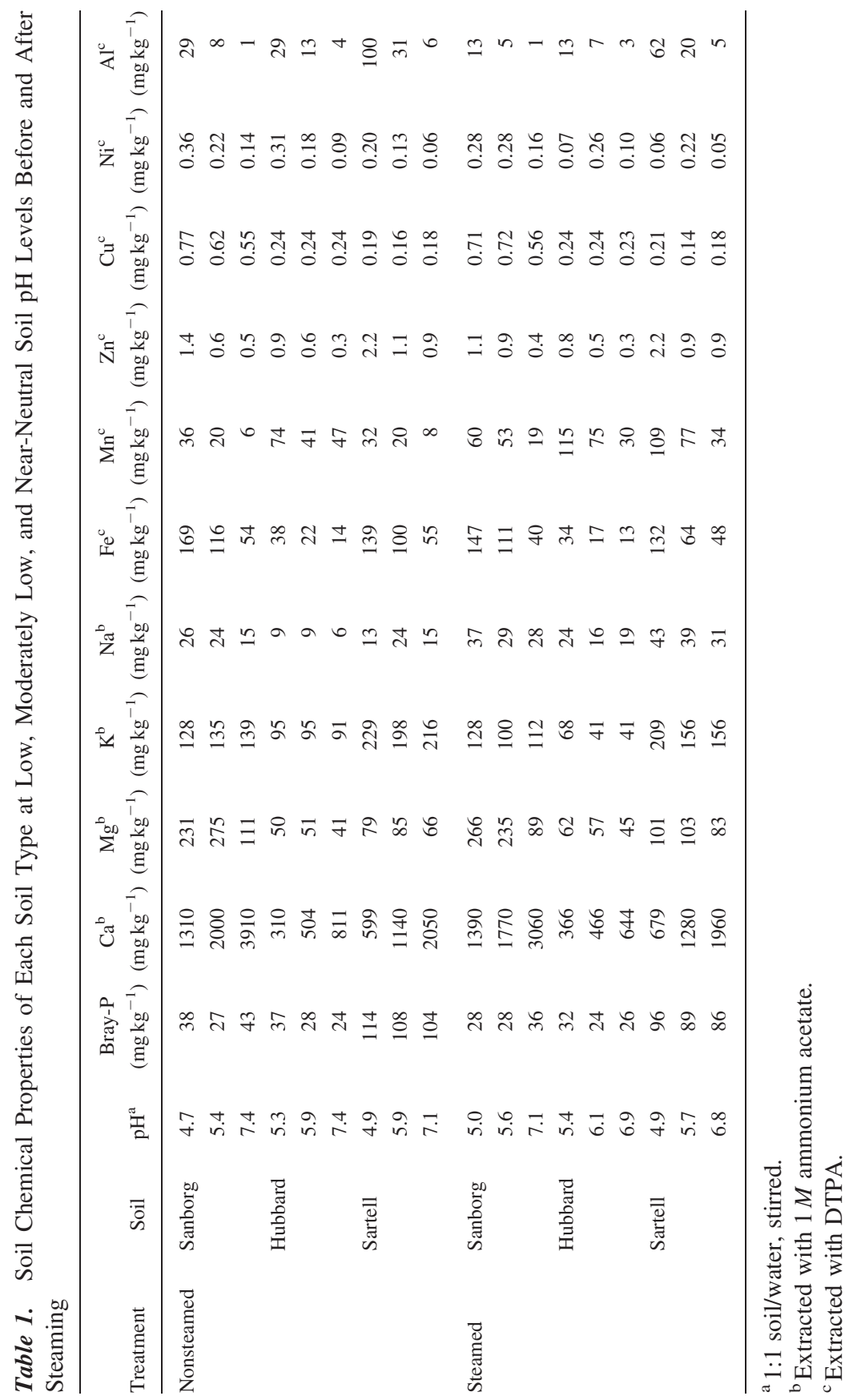


The shoot material from the second harvest was ground in a cyclone mill with a 1-mm screen and collected in plastic screw-top bottles. The samples were tumbled in a plastic drum turning at $15 \mathrm{rpm}$ for $20 \mathrm{~min}$ to obtain homogeneity. Near infrared reflectance spectra (NIRS) were collected on all samples of sufficient size using a NIRS scanning monochromator, model 6500 (Foss North America, Inc., Eden Prairie, MN 55344) and NIRS version 4.0 software (Infrasoft International, Port Matilda, PA 16870). Reflectance data were recorded between 400 and $2500 \mathrm{~nm}$ wavelengths at 2-nm intervals. Laboratory elemental analysis was performed on 53 samples selected by the software to develop an NIRS equation for tissue mineral concentration. The laboratory analysis was conducted using simultaneous multi-element Inductively Coupled Plasma-Atomic Emission Spectrometry (ICP-AES) $(17,18)$. The laboratory values were compared to the values calculated by the NIRS equation, and the NIRS equation adequately predicted tissue concentrations of $\mathrm{P}, \mathrm{K}, \mathrm{Ca}, \mathrm{Mg}$, and $\mathrm{Mn}\left(r^{2}>0.87\right)$. Tissue $\mathrm{N}$ content was approximated using a previously developed NIRS equation.

The experiment used a factorial arrangement of treatments with three soil types by three cultivars (two kura clover and one birdsfoot trefoil) by six soil $\mathrm{pH}$ levels in a randomized complete block design with three replications. Each experimental unit consisted of a single pot with nine plants. Because soil $\mathrm{pH}$ was somewhat different in every pot, regression analysis was used to determine the response of first harvest shoot, second harvest shoot, and root dry matter production to soil $\mathrm{pH}$. Responses of the three yield components were similar, so all further analysis was conducted using total biomass yield (root and both shoot harvests combined). The analysis was begun by fitting a model with separate intercept, linear, and quadratic terms for each treatment combination (soil type and cultivar). Quadratic or linear terms were deleted from the model when their removal resulted in a simplified model that was still adequate when compared to the full model by an $F$-test $(p>0.05)$. Due to highly significant interactions, the extremely complex model of a separate slope and intercept for every treatment combination could not be simplified. Because soil $\mathrm{pH}$ levels were slightly different for every treatment, mean yields could not be computed for specific soil $\mathrm{pH}$ levels. Instead, the regression model for each treatment combination was used to calculate predicted yield values at $\mathrm{pH} 4.9$ and 6.5. To examine the relationship between soil mineral concentration and plant yield, regression analysis was performed between total biomass yield and $\mathrm{P}$ and $\mathrm{Mn}$ tissue concentrations. Tissue concentrations of other minerals were either within acceptable ranges in all samples or not adequately predicted by NIRS equations. All statistical calculations were performed with S-Plus 4.5 (19). 


\section{RESULTS AND DISCUSSION}

\section{Soil Properties}

Amending the soils with $\mathrm{Ca}(\mathrm{OH})_{2}$ effectively produced a range in soil $\mathrm{pH}$ from less than 5 to about 7.5 in the Sanborg and Hubbard soils. The Sartell soil ranged from about $\mathrm{pH} 4.5$ to 7 . After steaming, the $\mathrm{pH}$ of the Hubbard and Sartell soils ranged from about 5 to 7 , and the Sanborg soil $\mathrm{pH}$ ranged from less than 5 to greater than 7, but there were no treatments between pH 6 and 7 .

Many soil chemical properties varied by soil and were apparently altered by liming and steaming (Table 1). In most cases, liming decreased extractable Fe, $\mathrm{Mn}, \mathrm{Zn}$, and $\mathrm{Al}$, and consistently increased extractable $\mathrm{Ca}$. Extractable $\mathrm{Al}$ and $\mathrm{K}$ were substantially decreased after steaming, but extractable Mn increased. At pH $<5.5$, extractable $\mathrm{P}$ was consistently reduced by steaming. The Sartell soil had the highest levels of extractable $\mathrm{P}, \mathrm{K}$, and $\mathrm{Al}$ at all $\mathrm{pH}$ levels.

\section{Yield Response to Soil pH}

On nonsteamed soil, kura clover biomass yield was influenced by soil $\mathrm{pH}$ in every combination of soil and cultivar except Rhizo grown on the Hubbard soil (Fig. 1). Norcen birdsfoot trefoil, however, did not respond to $\mathrm{pH}$ on any of the nonsteamed soils. Increasing the $\mathrm{pH}$ of the Sartell soil from 4.9 to 6.5 increased biomass yield of Endura and Rhizo by 52 and 33\%, respectively. Increasing the $\mathrm{pH}$ of the Hubbard soil from 4.9 to 6.5 increased biomass yield of Endura by $22 \%$. These yield increases were comparable to increases in the yield of established kura clover obtained by liming (11). Liming the nonsteamed Sanborg soil did not increase biomass yield of kura clover.

In the second trial, which used steamed soil, kura clover biomass yield was influenced by soil $\mathrm{pH}$ in every combination of soil and cultivar (Fig. 1). Norcen birdsfoot trefoil biomass yield was influenced by $\mathrm{pH}$ only on the Sanborg soil. On the Sanborg soil, the yield response of all cultivars to soil $\mathrm{pH}$ was quadratic. The quadratic trend was due to very low yields at soil $\mathrm{pH}>7$. This yield reduction was likely associated with a loss of soil structure similar to that documented for Ultisols and Oxisols (9). Over-liming of clay soils like Sanborg is expensive given the high lime requirement and may be detrimental. Increasing $\mathrm{pH}$ of the Sanborg soil from 4.9 to 6.5 increased biomass yield of Endura, Rhizo, and Norcen by 135,88 , and $38 \%$, respectively. Increasing soil $\mathrm{pH}$ from 4.9 to 6.5 increased biomass yield of Endura and Rhizo on Hubbard soil by 74 and 105\%, respectively, and on Sartell soil by 169 and 104\%, respectively.

Biomass yields were substantially lower in the second trial with steamed soil than in the first trial with nonsteamed soil (Fig. 1). This effect may be 


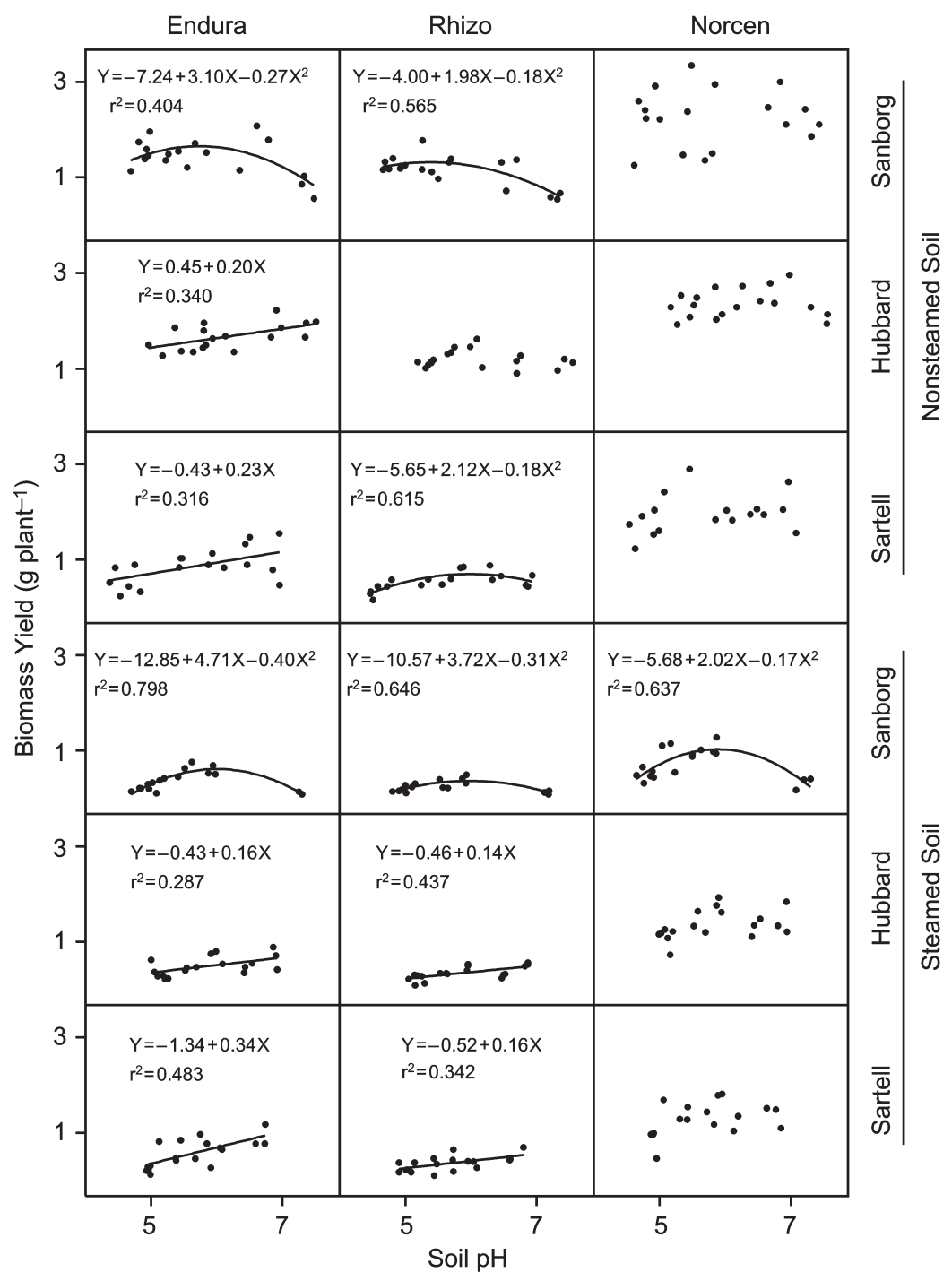

Figure 1. Relationship between soil $\mathrm{pH}$ and biomass yield (root and two shoot harvests) of Endura and Rhizo kura clover and Norcen birdsfoot trefoil. Regression lines are significant at $p<0.05$. 
partially due to day length or other environmental differences between the two trials, but soil steaming is known to have a detrimental effect on growth of legume seedlings (20).

\section{Plant Tissue Mineral Concentrations}

Minimum and maximum mineral concentrations were compared to the critical and toxic levels of these minerals for Trifolium repens L., Trifolium pratense L., and Trifolium subterraneum L. (Table 2). Tissue K, Ca, Mg, Fe, $\mathrm{Cu}$, and $\mathrm{B}$ were within acceptable levels in the kura clover cultivars, but both $\mathrm{Mn}$ and $\mathrm{Zn}$ exceeded potentially toxic levels in some treatments at low $\mathrm{pH}$. Molybdenum fell below the level of detection on low $\mathrm{pH}$ soils and was potentially limiting to growth. Tissue concentration of $\mathrm{P}$ was below potentially critical levels in some acidic soil treatments. Unfortunately, Zn and Mo tissue concentrations were not adequately predicted with NIRS and were not investigated further.

Tissue Mn concentration was negatively correlated with biomass yield in 7 of the 12 kura clover/soil type combinations (Fig. 2) but was not correlated with biomass yield of birdsfoot trefoil. Tissue Mn concentration was negatively correlated $(p<0.001)$ with soil $\mathrm{pH}$ in all cultivars on all soils except nonsteamed Sanborg. The correlation between soil $\mathrm{pH}$, tissue Mn concentration, and biomass yield suggest Mn toxicity as a possible mechanism for limiting yield of kura clover at low $\mathrm{pH}$ on the soils used in this study.

Tissue $\mathrm{P}$ was correlated with biomass yield of Endura grown on steamed Sanborg soil and Rhizo grown on steamed Sanborg and Hubbard soils (Fig. 3). Because the relationship was present only on steamed soil, low P uptake is not likely to be a common mechanism by which kura clover yields are limited at low $\mathrm{pH}$ in these soils under field conditions. None of the soils used had particularly low extractable $\mathrm{P}$ concentrations because we added $\mathrm{P}$ to reduce the likelihood of deficiency.

\section{Visual Ratings}

The plants ranged from showing no chlorosis (rating $=1$ ) to $20 \%$ of the leaf area being chlorotic (rating $=5$ ). In the extreme cases, necrosis was also beginning in small spots. In the soil by cultivar treatments in which tissue $\mathrm{Mn}$ concentration was negatively correlated with biomass yield (Fig. 2), tissue Mn concentration was also correlated with chlorosis rating. Foliar chlorosis in kura clover was moderately correlated with tissue Mn concentration on nonsteamed soil (slope $=0.0021, r^{2}=0.329, p<0.001$ ) and well correlated 


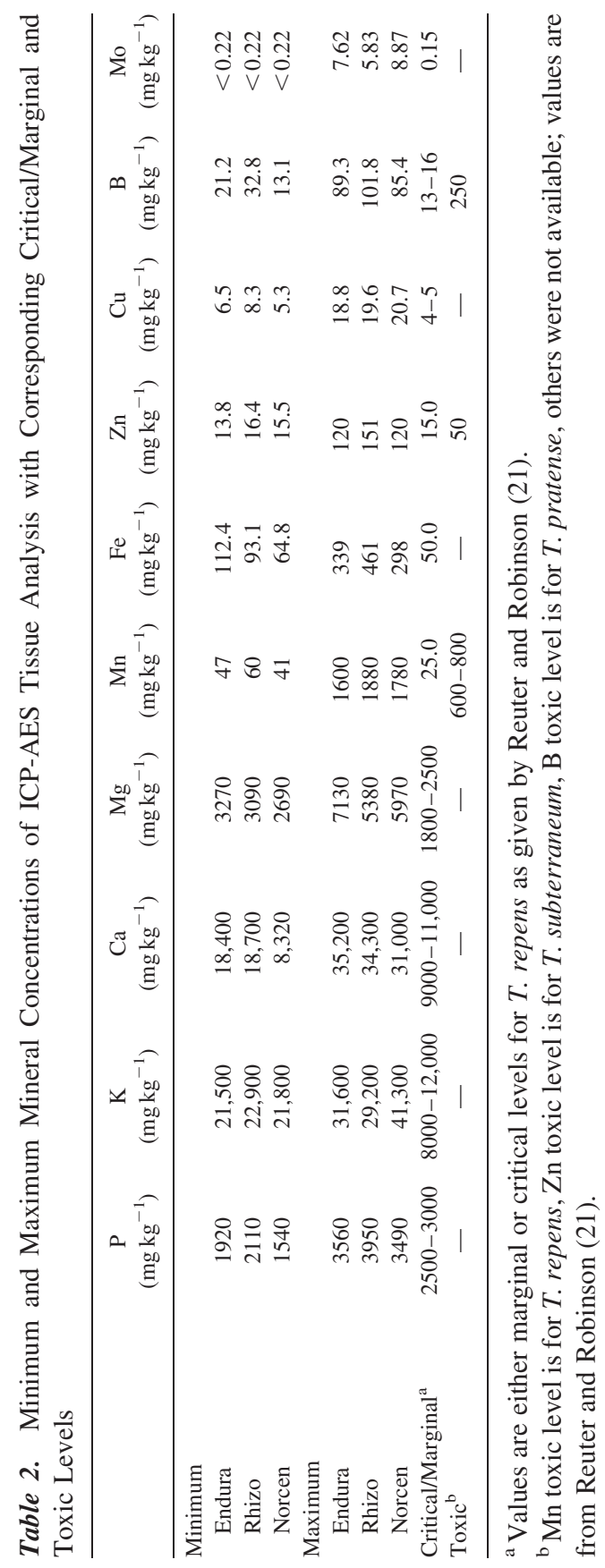



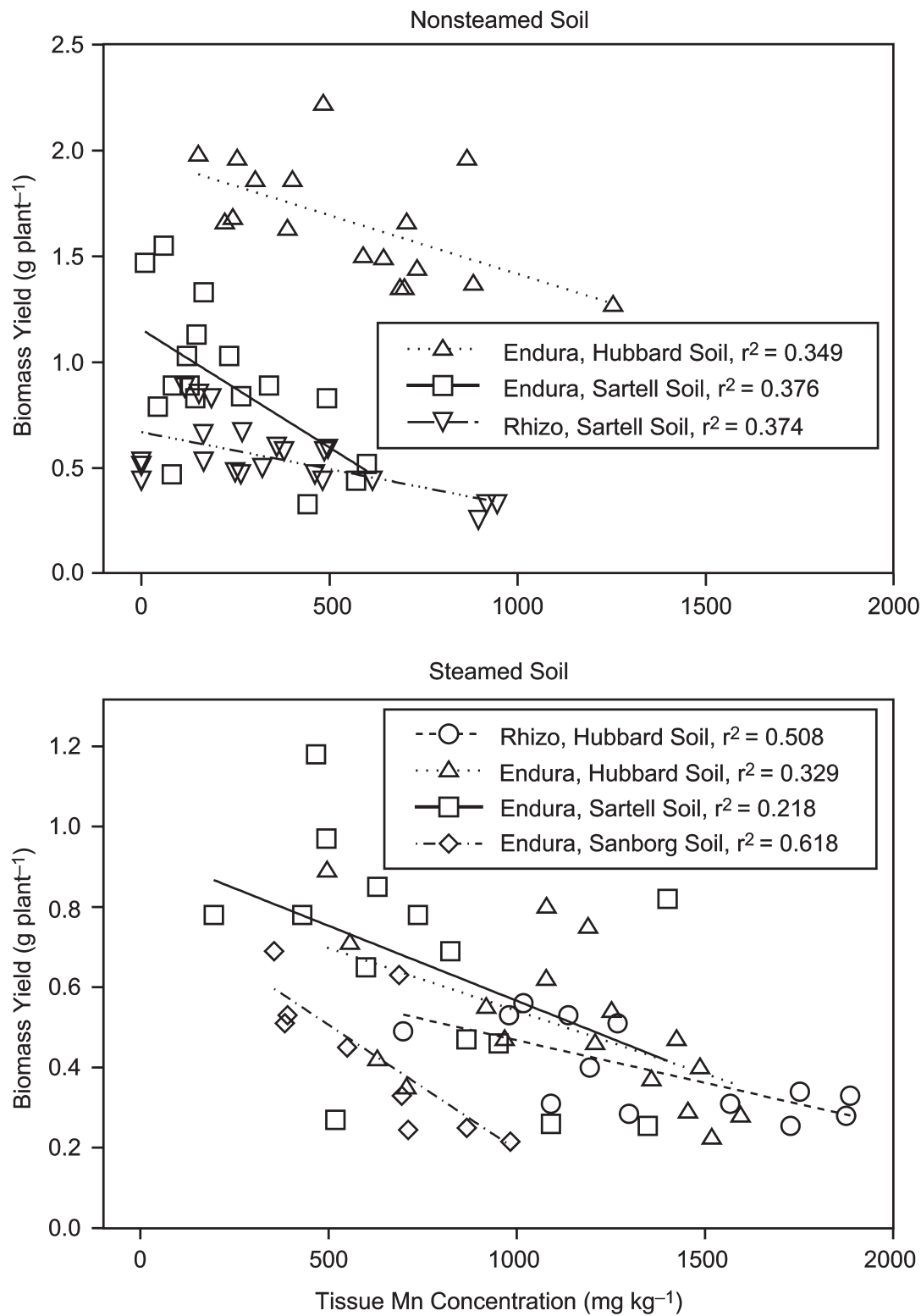

Figure 2. Relationship between tissue Mn concentration and biomass yield (root and two shoot harvests) of kura clover. Regression lines are significant at $p<0.10$. 


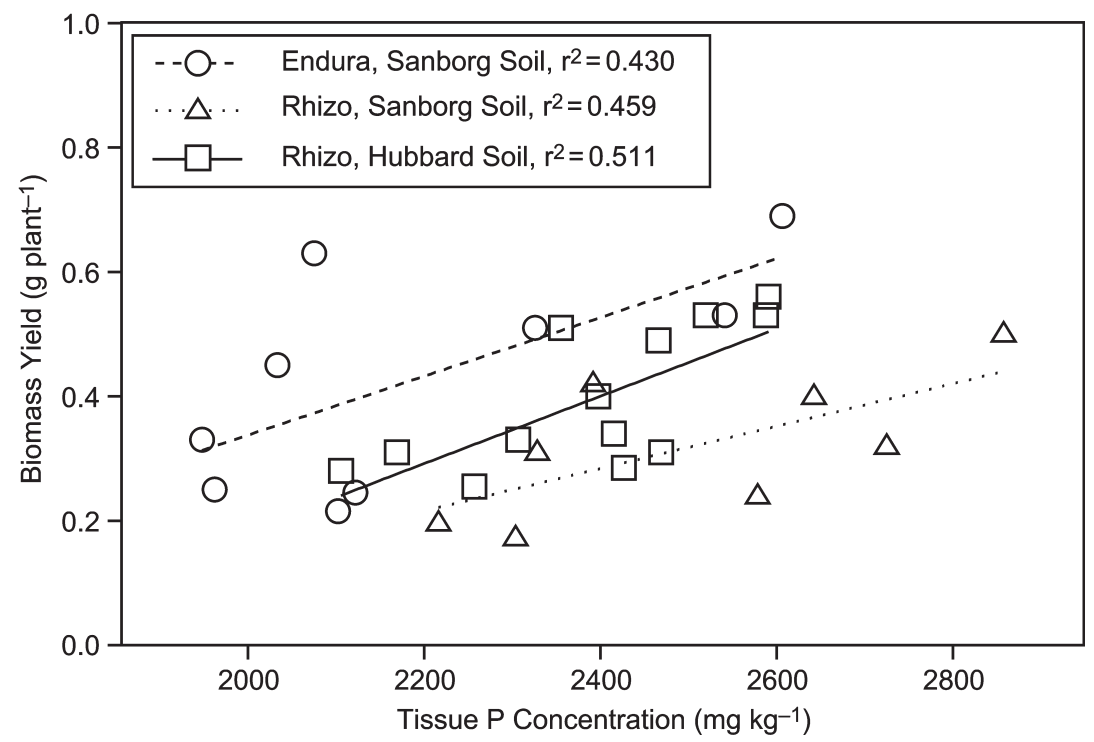

Figure 3. Relationship between tissue $\mathrm{P}$ concentration and biomass yield (root and two shoot harvests) of kura clover grown on steamed soil. Regression lines are significant at $p<0.10$.

with tissue $\mathrm{Mn}$ concentration on steamed soil (slope $=0.0023, r^{2}=0.656$, $p<0.001)$. The relationship between tissue $\mathrm{Mn}$ concentration and leaf chlorosis shows that chlorosis is a good indicator of Mn toxicity in kura clover. The chlorosis occurred primarily at the leaf margins, which is a typical Mn toxicity symptom (21). Leaf chlorosis was not observed on Norcen in any soil treatment, suggesting that it is probably tolerant of high foliar concentrations of $\mathrm{Mn}$, or that chlorosis is not a typical symptom of this condition (22).

The plants ranged from having no nodules (rating $=1$ ) to being heavily nodulated (rating $=5$ ). In the first trial, nodulation was only rated for the kura clover cultivars on the Hubbard soil, because high clay and organic matter content made washing difficult on the other soils. Both kura cultivars had significant linear increases in nodule rating with increasing soil $\mathrm{pH}$ (slope $=$ $\left.0.899, r^{2}=0.356, p<0.001\right)$. In the second trial, nodulation was rated for all cultivars on all soils. No responses were seen on the Sanborg soil. On the Hubbard soil, Endura (slope $=0.964$ ) and Norcen (slope $=0.790$ ) had significant linear increases in nodule rating with increasing $\mathrm{pH}\left(r^{2}=0.633\right.$, $p<0.001)$. On the Sartell soil, both kura clover cultivars had significant linear 
increases in nodule rating with increasing $\mathrm{pH}$ (slope $=0.357, r^{2}=0.287, p<$ 0.001).

Across all soils, total biomass yield of kura clover (slope $=0.767 \mathrm{X}-$ $0.090 \mathrm{X}^{2}, r^{2}=0.499, p<0.001$ ) and birdsfoot trefoil (slope $=0.211, r^{2}=$ $0.407, p<0.001)$ increased with increasing nodule rating. Nitrogen uptake ( $^{\text {g plant }}{ }^{-1}$ ) also increased with increasing nodule rating in kura clover (slope $=$ $\left.0.010 \mathrm{X}-0.001 \mathrm{X}^{2}, r^{2}=0.421, p<0.001\right)$. In birdsfoot trefoil, $\mathrm{N}$ uptake was not correlated with nodule rating. Therefore, reduced nodulation of kura clover at low soil $\mathrm{pH}$ probably limited plant growth through a reduction of biological $\mathrm{N}_{2}$ fixation, but reduced nodulation of birdsfoot trefoil did not affect plant growth. This result is consistent with the finding that kura clover seedling growth is highly dependent upon nitrogen availability (4). Birdsfoot trefoil may be more capable of taking up soil $\mathrm{N}$ in acid soils that limit nodulation and biological $\mathrm{N}_{2}$ fixation.

\section{CONCLUSIONS}

Kura clover was more consistently responsive to increased soil $\mathrm{pH}$ than Norcen birdsfoot trefoil during establishment. Biomass yield increases of up to $52 \%$ in kura clover were obtained by increasing the $\mathrm{pH}$ of nonsteamed soil from 4.9 to 6.5 . Increases in young plant growth of this magnitude justify liming sandy soils similar to Hubbard or Sartell to $\mathrm{pH}>6.0$ before establishing kura clover. Liming of the Sanborg soil is not recommended because increasing $\mathrm{pH}$ of this soil in the nonsteamed trial produced little positive impact on plant growth. Field studies are needed to verify these results and determine economically optimum $\mathrm{pH}$ levels.

Increases in biomass yields of kura clover on soils such as those used in this study are most likely due to alleviation of $\mathrm{Al}, \mathrm{Mn}$, or $\mathrm{Zn}$ toxicities, and in some cases, increased availability of $\mathrm{P}$ or Mo. Extractable Al decreased with liming, and legume seedlings are known to be sensitive to Al (23). All low-pH nonsteamed soils had extractable Al concentrations higher than the concentration (DTPA-Al $=27 \mathrm{mg} \mathrm{kg}^{-1}$ ) suspected of causing injury to birdsfoot trefoil roots (24). Foliar chlorosis and reduced biomass yield were correlated with tissue $\mathrm{Mn}$ concentration in some kura clover treatments, but not in birdsfoot trefoil. Some plant species are tolerant of high Mn concentrations in their foliage $(7,25)$; our results indicate that birdsfoot trefoil may be a tolerant species.

Root systems of kura clover grown on sandy soils generally showed evidence of increased nodule size and abundance in response to increased soil $\mathrm{pH}$, demonstrating that the growth or activity of the rhizobia is inhibited by low soil $\mathrm{pH}$. On acid soils, liming will probably be required to obtain maximum levels of $\mathrm{N}_{2}$ fixation in kura clover. 


\section{ACKNOWLEDGMENTS}

Names are necessary to report factually on available data, however, the USDA and the University of Minnesota neither guarantee nor warrant the standard of the product, and the use of the name by the USDA and the University of Minnesota implies no approval of the product to the exclusion of others that may be suitable.

\section{REFERENCES}

1. Sheaffer, C.C.; Marten, G.C.; Jordan, R.M.; Ristau, E.A. Forage Potential of Kura Clover and Birdsfoot Trefoil When Grazed by Sheep. Agron. J. 1992, 84, 176-180.

2. Speer, G.S.; Allison, D.W. Kura Clover (Trifolium ambiguum ): Legume for Forage and Soil Conservation. Econ. Bot. 1985, 39, 165-176.

3. Seguin, P.; Sheaffer, C.C.; Ehlke, N.J.; Becker, R.L. Kura Clover Establishment Methods. J. Prod. Agric. 1999, 12, 483-487.

4. Seguin, P.; Sheaffer, C.C.; Ehlke, N.J.; Russelle, M.P.; Graham, P.H. Kura Clover Seeding Year Growth and $\mathrm{N}_{2}$ Fixation: Effects of Nitrogen Fertilization and Rhizobial Inoculation. Agron. J. 2000, 92, 1216-1220.

5. Taylor, N.L.; Smith, R.R. Kura Clover (Trifolium ambiguum M.B.) Breeding, Culture, and Utilization. Adv. Agron. 1998, 63, 153-178.

6. Tisdale, S.L.; Nelson, W.L.; Beaton, J.D. Soil Fertility and Fertilizers; Macmillan Publishing Company: New York, NY, 1985.

7. Marschner, H. Mineral Nutrition of Higher Plants, 2nd Ed.; Academic Press: San Diego, CA, 1995.

8. Rice, W.A.; Penney, D.C.; Nyborg, M. Effects of Soil Acidity on Rhizobia Numbers, Nodulation, and Nitrogen Fixation by Alfalfa and Red Clover. Can. J. Soil Sci. 1977, 57, 197-203.

9. Kamprath, E.J. Potential Detrimental Effects from Liming Highly Weathered Soils to Neutrality. Soil Crop Sci. Soc. Florida Proc. 1971, 31, 200-203.

10. Grant, W.F.; Marten, G.C. Birdsfoot Trefoil. In Forages: The Science of Grassland Agriculture; 4th Ed. Heath, M.E., Barnes, R.F., Metcalfe, D.S., Eds.; Iowa State University Press: Ames, IA, 1985; 98-108.

11. Rehm, G.; Schmitz, D.; Scobbie, A.; Sheaffer, C.; Martin, N. Lime Requirements of Five Forage Legumes Grown on an Irrigated Sandy Soil: Field Research in Soil Science 1993; Misc. Publ. 79-1993, Minnesota Agricultural Experiment Station, University of Minnesota: St. Paul, MN, 1993. 
12. Barnard, R.O.; Folscher, W.J. Growth of Legumes at Different Levels of Liming. Trop. Agric. 1988, 65, 113-116.

13. Bryant, W.G. Caucasian Clover (Trifolium ambiguum, Bieb.): A Review. J. Aust. Inst. Agric. Sci. 1974, 104, 227-229.

14. Barnard, C. Register of Australian Herbage Cultivars; CISRO, Aust. Div. Plant Ind.: Canberra, Australia, 1972; 148-151.

15. Henry, D.S.; Taylor, N.L. Registration of 'Rhizo' Kura Clover. Crop Sci. 1989, 29, 1572.

16. Miller, D.A.; Beuselinck, P.R.; Carlson, I.T.; Elling, L.J. Norcen Birdsfoot Trefoil. Crop Sci. 1983, 23, 1010-1011.

17. Munter, R.C. Quality Assurance for Plant Tissue Analysis by ICP-AES. Commun. Soil Sci. Plant Anal. 1984, 15, 1285-1322.

18. Munter, R.C.; Grande, R.A. Plant Tissue and Soil Extract Analysis by ICPAtomic Emission Spectrometry. In Developments in Atomic Plasma Spectrochemical Analysis; Barnes, R.M., Ed.; Heyden and Son Ltd.: Philadelphia, PA, 1981; 653-671.

19. Mathsoft, S-PLUS 4 Guide to Statistics; Data Analysis Products Division, Mathsoft: Seattle, WA, 1997.

20. Robinson, R.R. Inhibitory Plant Growth Factors in Partially Sterilized Soils. Agron. J. 1944, 36, 726-739.

21. Reuter, D.J.; Robinson, J.B., (Eds.) Plant Analysis: An Interpretation Manual, 2nd Ed.; CSIRO Pub.: Collingwood, VIC, Australia, 1997.

22. Russelle, M.P.; McGraw, R.L. Nutrient Stress in Birdsfoot Trefoil. Can. J. Plant Sci. 1986, 66, 933-944.

23. MacLeod, L.B.; Jackson, L.P. Effect of the Concentration of the Al Ion on Root Development and Establishment of Legume Seedlings. Can. J. Soil Sci. 1965, 45, 221-234.

24. Kallenbach, R.L.; McGraw, R.L.; Beuselinck, P.R. Soil pH Effects on Growth and Mineral Concentration of Birdsfoot Trefoil. Can. J. Plant Sci. 1996, 76, 263-267.

25. Horst, W.J. The Physiology of Mn Toxicity. In Mn in Soils and Plants: International Symposium on Mn in Soils and Plants; Graham, R.D., Hannam, R.J., Uren, N.C., Eds.; Kluwer Academic Publishers: Boston, MA, 1988; 175-188. 